\title{
Obesity alters the ovarian DNA damage response and apoptotic proteins
}

\author{
Kendra L Clark, Crystal M Roach and Aileen F Keating \\ Department of Animal Science, lowa State University, Ames, lowa, USA \\ Correspondence should be addressed to A F Keating; Email: akeating@iastate.edu
}

\begin{abstract}
In the overweight or obese female, reproductive complications include poor oocyte quality, decreased fecundity, gestational diabetes, and higher risk of reproductive cancers. Using lean and hyperphagia-induced obese female mice aged 10 weeks, we determined that the ovary from obese female mice had elevated $(P<0.10)$ levels of ataxia telangiectasia mutated (ATM) protein in oocytes of both small and large follicles. Phosphorylated ATM at serine 1981 was greater $(P<0.05)$ in large relative to small follicles with no additional impact of obesity. Obesity increased $(P<0.05) \gamma \mathrm{H} 2 \mathrm{AX}$ in small follicles in obese relative to lean ovaries, while large follicles of both lean and obese mice had detectable levels of $\gamma \mathrm{H} 2 \mathrm{AX}$. Cleaved caspase 3 was reduced $(P<0.05)$ in the small follicles of obese relative to lean ovaries. In large follicles of lean mice, cleaved caspase 3 was increased in large compared to small follicles $(P<0.05)$ but this pattern was absent in obese mice. Breast cancer type 1 susceptibility protein (BRCA1) or the phosphorylated BRCA1 proteins were observably altered by obesity. These data demonstrate that markers of DNA damage and repair have a follicledependent stage location and that obesity alters ATM and cleaved caspase 3 in a follicular stage dependent manner.

Reproduction (2020) $\mathbf{1 6 0} 751-760$
\end{abstract}

\section{Introduction}

Obesity is a preventable metabolic syndrome, associated with several interrelated disorders such as insulin resistance/diabetes (Colditz et al. 1995), cardiovascular disease (Lavie et al. 2009), dyslipidemia (Kang et al. 2016), chronic inflammation (Xu et al. 2003), and cancer (Cozzo et al. 2017). The prevalence of obesity in the population continues to rise, with an estimated $40 \%$ of adults and $19 \%$ of youth being obese/ overweight in the United States, though these rates are higher for some ethic groups (Hales 2017). A decline in reproductive potential is associated with obesity, and reproductive complications include poor oocyte quality (Brewer \& Balen 2010), polycystic ovary syndrome (PCOS) (Pasquali \& Casimirri 1993), decreased fecundity (Gesink Law et al. 2007), impaired pregnancy success using assisted reproductive technologies (Metwally et al. 2007), gestational diabetes (Chu et al. 2007), and increased risk of offspring health problems (Sheffield et al. 2002).

The ovary is the source of the female germ cell, the oocyte, and hormones necessary for female growth and development. Throughout the female lifespan, a finite pool of primordial germ cells will remain in diplotene stage of meiosis until they are primed for maturation toward ovulation and subsequent fertilization, or they undergo atresia (Hirshfield 1991). Once the primordial follicle pool is depleted, ovarian senescence occurs
(Hirshfield 1991). Depletion of follicles prior to age 40 is termed primary ovarian insufficiency with often unknown etiology (Coulam et al. 1986). Cessation of or dysfunctional ovarian activity predisposes women toward at heightened risk for development of gynecological cancers (Nagle et al. 2015), osteoporosis (Compston 2001), cardiovascular disease (Mosca et al. 1997), and Alzheimer's disease (Scheyer et al. 2018).

Accumulation of DNA damage is considered a contributing factor to obesity-related disorders due to the chronic low-grade inflammation and constant production of reactive oxygen species (ROS) that may induce endogenous DNA damage throughout the body (Cerda et al. 2014, Wlodarczyk et al. 2018, Zaki et al. 2018). Obesity is also associated with ovarian DNA damage (Ganesan et al. 2014, 2015, 2017) and increased granulosa cell apoptosis (Walzem \& Chen 2014). The cellular DNA damage response (DDR) prevents genomic damage by either repairing the damage or triggering the cell toward apoptosis if beyond repair. Central metabolic disturbances during obesity have adverse impacts on the DDR (Himbert et al. 2017, Azzara et al. 2016). We have previously demonstrated that progressive obesity alters ovarian folliculogenesis and inflammation (Nteeba et al. 2014b), the insulin responsive phosphatidylinositol 3-kinase (PI3K) pathway (Nteeba et al. 2013), steroid hormone biosynthesis (Nteeba et al. 2017), causes basal DNA damage and affects the response to genotoxicant 
exposures (Ganesan et al. 2014, 2017, Nteeba et al. 2014a, 2017).

Ataxia telangiectasia mutated (ATM) protein is a key DDR initiator, sensing DNA damage and transducing downstream targets including breast cancer type 1 susceptibility protein (BRCA1) for DNA repair (Gatei et al. 2000); serine/threonine-protein kinase Chk2 (CHK2) for cell cycle arrest (Falck et al. 2001); p53 for apoptosis (Meulmeester et al. 2005) and RAC-alpha serine/ threonine-protein kinase (AKT) for cell survival (Liu et al. 2014). Despite hyperphagia-induced obese mice having an increase in ATM protein in response to a genotoxic chemical, we have previously demonstrated lack of an appropriate response in the proteins downstream of ATM (Ganesan et al. 2014, 2017). This finding provided the rationale for the hypothesis that ATM-mediated DDR and follicular atresia proteins are altered by obesity with impacts of follicle maturation stage. This study employed a mouse model of hyperphagia-induced obesity (Duhl et al. 1994, Michaud et al. 1994, Klebig et al. 1995) in which increased feed intake is a phenotype (Koegler et al. 1999, Bazhan et al. 2013). We chose this model based upon our previous characterization of the impact of obesity on a variety of ovarian endpoints, including DDR protein abundance (Nteeba et al. 2013, 2014a,b, 2017, Ganesan et al. 2014, 2017). In addition, the mice were 10 weeks of age, an intermediate point when there is no difference in body weight at 6 weeks of age and when the hyperphagic mice are heavier than their lean controls at 12 weeks of age (Yang et al. 2012). This approach facilitated the investigation of initiating events to induce an aberrant ovarian DDR.

\section{Materials and methods}

\section{Animal procedure and tissue collection}

All experiments were performed according to regulatory guidelines and approved by the Institutional Animal Care and Use Committee (IACUC) at lowa State University. Female WT normal non-agouti (a/a; $n=10$; designated lean) and agouti lethal yellow (KK. Cg-Ay/J mice; $n=10$; designated obese) were purchased from Jackson laboratory (Bar Harbor) and maintained in an animal facility at lowa State University under controlled room temperature $\left(21^{\circ} \mathrm{C}-22^{\circ} \mathrm{C}\right)$ and lighting (12h light : $12 \mathrm{~h}$ darkness) with access to food and water ad libitum. At 10 weeks of age, mice were euthanized in the proestrus phase of the estrous cycle and ovaries were fixed in $4 \%$ paraformaldehyde overnight at $4^{\circ} \mathrm{C}$ for histological analysis.

\section{Estrous cycle monitoring}

The estrous cycle was monitored by performing daily vaginal cytological analysis in the morning for 7 days to ensure mice were at the same stage of the estrous cycle upon euthanasia. Fresh, wet vaginal smears were collected by pipetting saline into the vagina, smearing onto histology slides and examining with a Nikon Optiphot microscope using a 10x objective. Classification of estrous cycle stages was determined as previously described (Byers et al. 2012). Briefly, pro-estrus was characterized by small, round nucleated epithelial cells, some cornified epithelial cells, and little to no leukocytes. Estrus was characterized by several cornified epithelial cells containing pyknotic nuclei. The presence of cornified cells and leukocytes indicated metestrus. In diestrus, nucleated epithelial cells reappeared in the vaginal smears in addition to the presence of polymorphonuclear leukocytes. Obese mice who displayed persistent diestrus $(n=4)$ were subsequently excluded from further analysis.

\section{Histology}

After fixation, ovaries were passed through a $10,20 \% / 0.1 \mathrm{M}$ PBS gradient for 1-3 $\mathrm{h}$ each at room temperature, followed by $30 \%$ sucrose $/ 0.1 \mathrm{M}$ PBS overnight at $4{ }^{\circ} \mathrm{C}$ and embedded in optimal cutting temperature (OCT; Fisher healthcare) compound before being flash frozen on dry ice. Ovaries were serially sectioned at $7 \mu \mathrm{m}$ with a maximum of three sections per slide.

\section{Immunofluorescence staining}

Slides were warmed briefly on a $37^{\circ} \mathrm{C}$ slide warmer and tissue sections were encircled with a histology pap pen (Vector laboratories) to maintain staining solutions concentrated on the tissue during processing. Tissue was rehydrated and permeabilized in $0.1 \mathrm{M} \mathrm{PBS}$ with $0.1 \%$ Tween 20 (PBSTw) for 20 min, followed by blocking ( $0.1 \mathrm{M} \mathrm{PBS} / 1 \% \mathrm{BSA} / 1 \% \mathrm{DMSO} / 5 \%$ goat serum) for $60 \mathrm{~min}$ at room temperature. Primary antibodies (Supplementary Table 1, see section on supplementary materials given at the end of this article) were diluted in fresh blocking solution, applied to the tissue sections and incubated in a humidified box at $4^{\circ} \mathrm{C}$ overnight. For antigen retrieval, $1 \%$ sodium dodecyl sulfate (SDS; Sigma Aldrich) was applied for 5 min after the rehydration step, followed by three washes of PBSTw for 5 min each and addition of blocking solution as described above. After primary antibody incubation, slides were washed three times in PBSTw for 10 min per wash. The appropriate secondary antibody (Supplementary Table 1) was added to fresh blocking solution, applied to tissue sections and incubated at room temperature for $60 \mathrm{~min}$, followed by four washes in PBSTw for 10 min per wash. Slides were air dried, followed by addition of Vectashield with DAPI (H1200, Vector Labs) and stored overnight at $4{ }^{\circ} \mathrm{C}$. Negative technical controls to confirm specificity were performed using secondary antibodies alone (Supplementary Fig. 1). Images were captured on a Zeiss LSM700 confocal microscope equipped with an AxioCam MRc5 using a 5 or $20 \times$ objective.

\section{Quantification of protein abundance}

For quantification of ATM ( $n=6$ ovaries per treatment; six sections per ovary), and pATM ( $n=6$ ovaries per treatment; six sections per ovary), the threshold percentage of the total image area was limited to the oocyte using ImageJ software (Schneider et al. 2012). For $\gamma \mathrm{H} 2 \mathrm{AX}$ (six ovaries per treatment; six sections per ovary) and cleaved CASP3 (six ovaries per 
treatment; six sections per ovary), immunopositive cells were manually counted in the granulosa cells of primary, secondary and antral follicles using the cell counter module of Image software (Schneider et al. 2012). Briefly, primary follicles were identified as containing an oocyte surrounded by a single layer of cuboidal granulosa cells; secondary follicles contained an oocyte surrounded by multiple layers of granulosa cells and antral follicles were identified by the presence of an oocyte enclosed by several layers of granulosa cells and concurrent presence of a fluid-filled antral space. For comparisons, small follicles are considered primary and early secondary follicles, while large follicles are considered late secondary follicles and antral follicles.

\section{Statistical analysis}

Statistical analyses were performed using GraphPad Prism 7.0 unpaired $t$-test function. A $P$-value $\leq 0.05$ was considered statistically significant and a trend for a statistical difference was considered at $P<0.1$. Values are expressed as mean \pm S.E.M.

\section{Results}

\section{Body weight is increased in female lethal yellow mice at 10 weeks of age}

Body weight was higher in agouti lethal yellow mice (henceforth designated obese) relative to WT controls (henceforth designated lean; $P<0.05$; Fig. 1A) at the onset of the experiment. The weights of the heart (Fig. 1B), spleen (Fig. 1D) and the uterus (Fig. 1F) from the obese females were reduced $(P<0.05)$ in comparison to lean controls, while the liver weight was increased $(P<0.05$; Fig. 1C) in obese females. There were no differences $(P>0.05)$ in the weights of the kidneys (Fig. 1E) or ovaries (Fig. 1G) between lean and obese mice.

\section{Obesity increases ovarian ATM protein abundance}

In order to establish the basal level of ovarian DDR proteins due to progressive obesity, both basal and phosphorylated levels of ATM protein were examined. Basal levels of ATM immunofluorescence were localized in the oocyte of all follicular stages with no difference in localization patterns between lean or obese mice (Fig. 2A, B, C and D). ATM oocyte immunoreactivity was elevated $(P<0.05)$ in both small and large follicles in the obese (Fig. $2 \mathrm{I}$ and $\mathrm{K}$ ) relative to the lean (Fig. 2J and L) ovary.

Phosphorylation of ATM at serine 1981 was present in the oocyte and granulosa cells of all follicular stages (Fig. $2 \mathrm{E}, \mathrm{F}, \mathrm{G}$ and $\mathrm{H}$ ). There were greater levels of pATM $^{\mathrm{Ser} 1981}$ in small follicles of the obese, relative to lean ovary (Fig. $2 \mathrm{M}$ ), but this was not the case in large follicles (Fig. 2O). In the lean ovary, pATM ${ }^{\text {Ser1981 }}$ was higher in large relative to small follicles (Fig. $2 \mathrm{~N}$ ) but this pattern was not observed in the obese ovary (Fig. 2P).
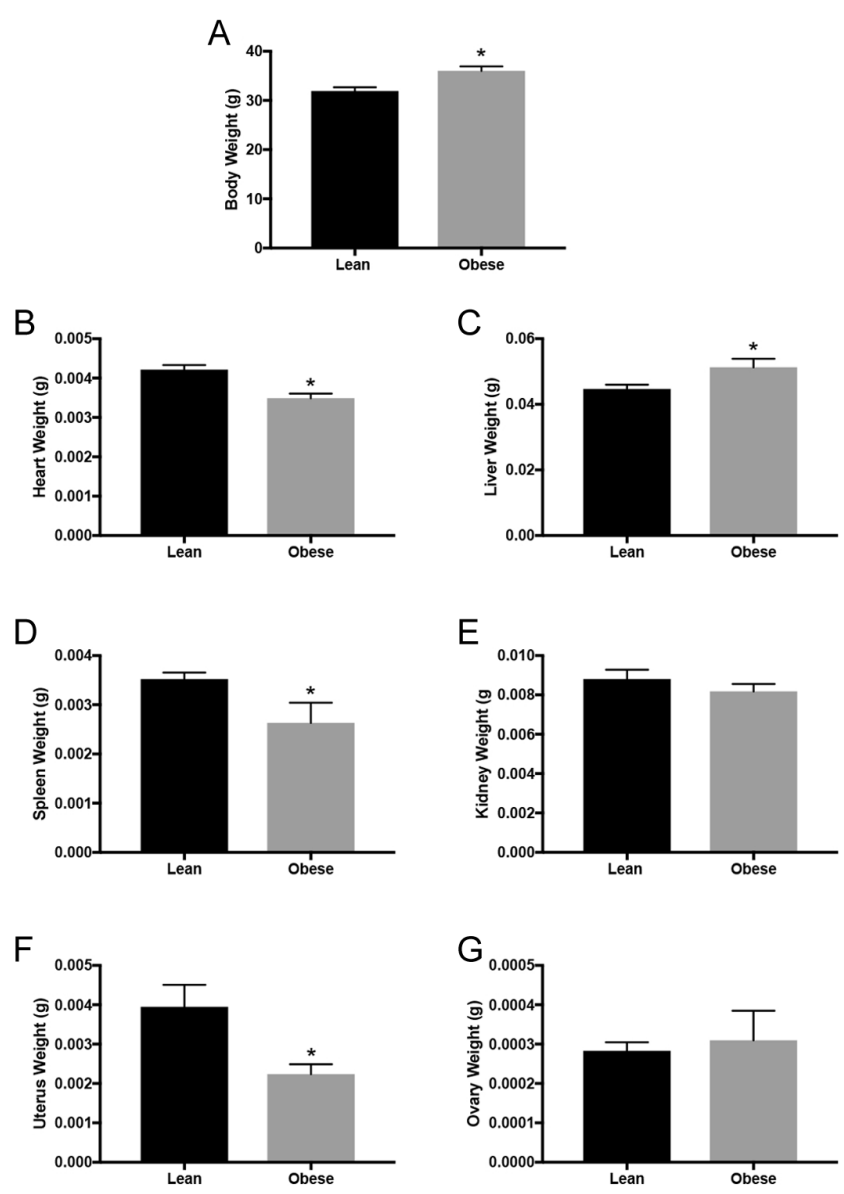

Figure 1 Effect of obesity on body and organ weight in female lethal yellow mice. Lean and obese mice were euthanized at 10 weeks of age in the proestrus stage of the estrous cycle. Tissues were collected and weights are presented as mean \pm S.E.M. (A) Body weight; (B) Heart; (C) Liver; (D) Spleen; (E) Kidney; (F) Uterus and (G) Ovary weights. Statistical significance $* P<0.05$.

\section{Obesity increases ovarian $\gamma \mathrm{H} 2 \mathrm{AX}$}

To determine if obesity leads to ovarian DNA double strand breaks (DSB), ovary sections were analyzed for localization of $\gamma \mathrm{H} 2 \mathrm{AX}$ and positive foci were quantified (Fig. 3). The number of ovarian cells (granulosa cells and/ or oocytes) that contained positive $\gamma \mathrm{H} 2 \mathrm{AX}$ foci tended $(P<0.1)$ to be greater in total (Fig. 3E), as well as in both small $(P<0.05)$ and large $(P<0.1)$ follicles (Fig. 3F and $G)$ in the obese relative to lean ovary. In both the lean and obese ovaries, larger follicles had more $(P<0.05)$ $\gamma \mathrm{H} 2 \mathrm{AX}$ positive foci than in smaller follicles (Fig. $3 \mathrm{H}$ and I).

\section{Apoptosis is not elevated in the obese ovary though a shift between follicle sizes occurs}

To determine if there is an increase in follicular atresia in the obese ovary, tissue sections were analyzed for cleaved CASP3 via immunofluorescence (Fig. 4A, B, C and $D$ ) and positive foci were quantified. The number of 

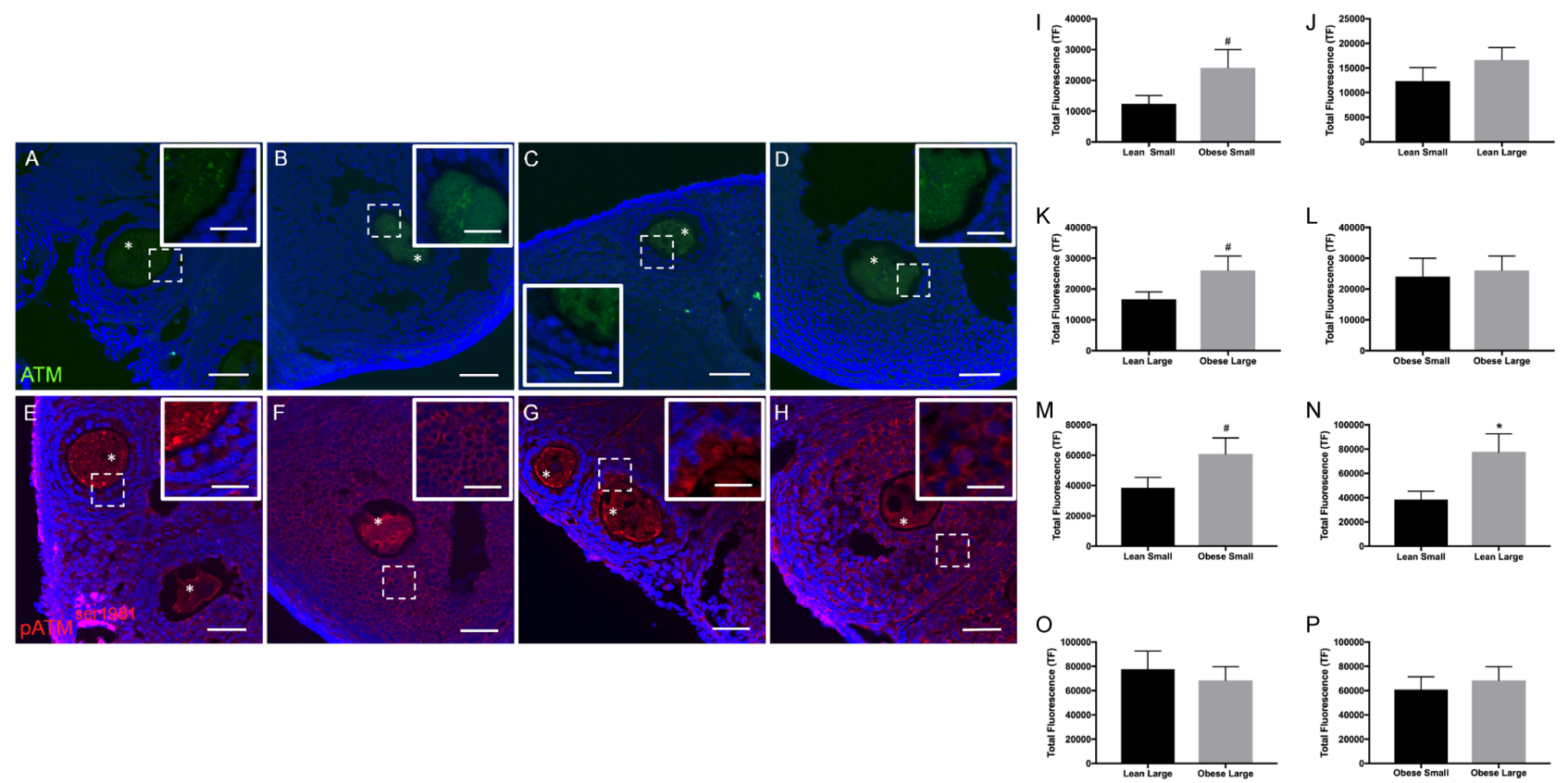

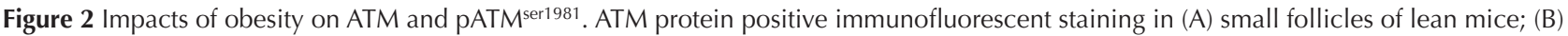
large follicles of lean mice; (C) small follicles of obese mice; (D) large follicles of obese mice, and pATM ${ }^{\text {ser1981 }}$; (E) small follicles of lean mice; (F) large follicles of lean mice; $(\mathrm{G})$ small follicles of obese mice; $(\mathrm{H})$ large follicles of obese mice. Green stain indicates ATM and red stain indicates pATM $^{\text {ser1981 }}$ while cellular DNA is stained in blue; scale bar $=50 \mu \mathrm{m}(25 \mu \mathrm{m}$ for insets). Asterisk indicates oocyte. Bar charts present mean fluorescence intensity \pm S S.E.M. of ATM in (I) small follicles; (J) lean small/large follicles; (K) large follicles; (L) obese

small/large follicles and of pATM ser1981; (M) small follicles; (N) lean small/large follicles; (O) large follicles; (P) obese small/large follicles $* P<0.05, "{ }^{*} P<0.1$.

total cleaved CASP3 positive granulosa cells were not different $(P>0.05)$ between the lean and obese mice (Fig. 4E). However, there were more $(P<0.05)$ CASP3 positive foci in smaller follicles of the lean versus the obese ovary (Fig. 4F) and more $(P<0.05)$ positive foci in the larger follicles relative to the smaller follicles in the obese ovary (Fig. 4I). There were no differences $(P>0.05)$ in numbers of positive CASP3 cells between the large follicles in lean and obese or between the follicle sizes in the lean ovaries alone (Fig. 4G and H).

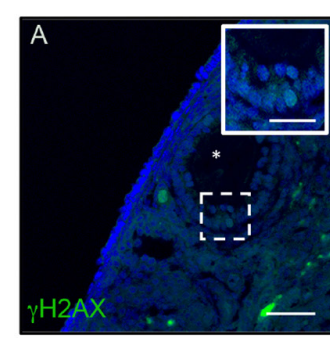

$\mathrm{F}$

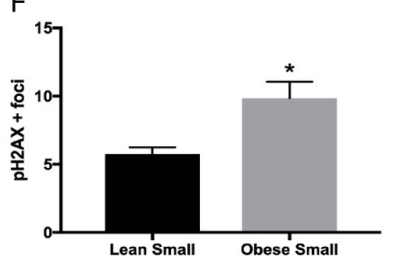

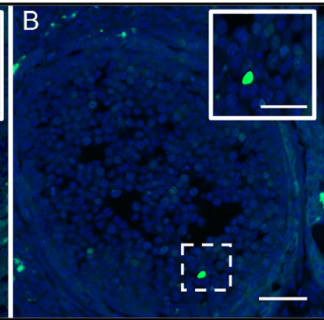

G

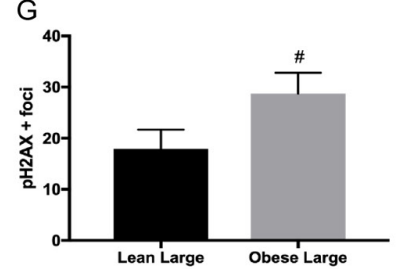

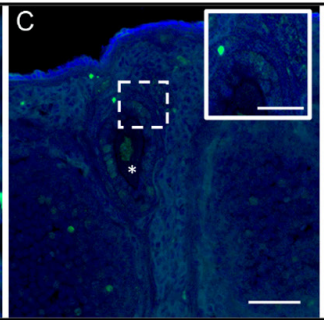

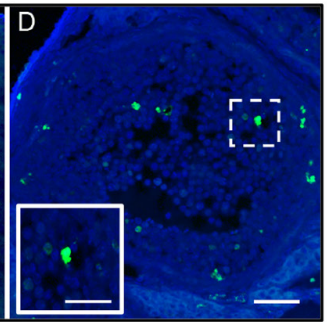

$\mathrm{H}$

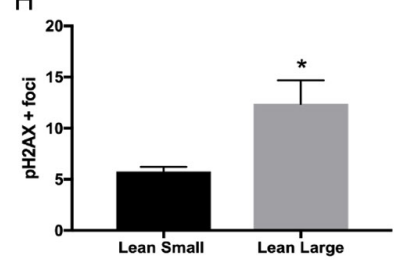

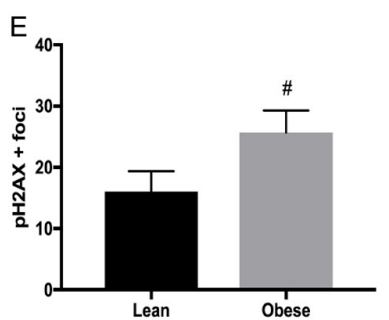

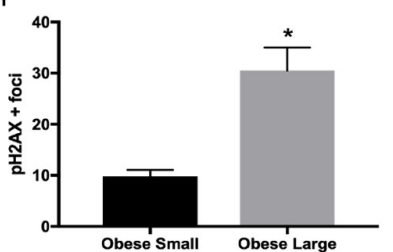

Figure 3 Effect of progressive obesity on ovarian $\gamma \mathrm{H} 2 \mathrm{AX}$ abundance. Positive immunolocalization for $\gamma \mathrm{H} 2 \mathrm{AX}$ in (A) small follicles of lean mice; (B) large follicles of lean mice; (C) small follicles of obese mice and (D) large follicles of obese mice. Green punctate stain indicates $\gamma \mathrm{H} 2 \mathrm{AX}$ while cellular DNA is stained in blue; scale bar $=50 \mu \mathrm{m}(25 \mu \mathrm{m}$ for insets). Asterisk indicates oocyte. Bar charts present mean number of positive $\gamma \mathrm{H} 2 \mathrm{AX}$ foci \pm S.E.M. in (E) all follicles; (F) small follicles; (G) large follicles; $(\mathrm{H})$ lean small/large follicles; (I) obese small/large follicles; $* P<0.05$, ${ }^{\# P}<0.1$. 

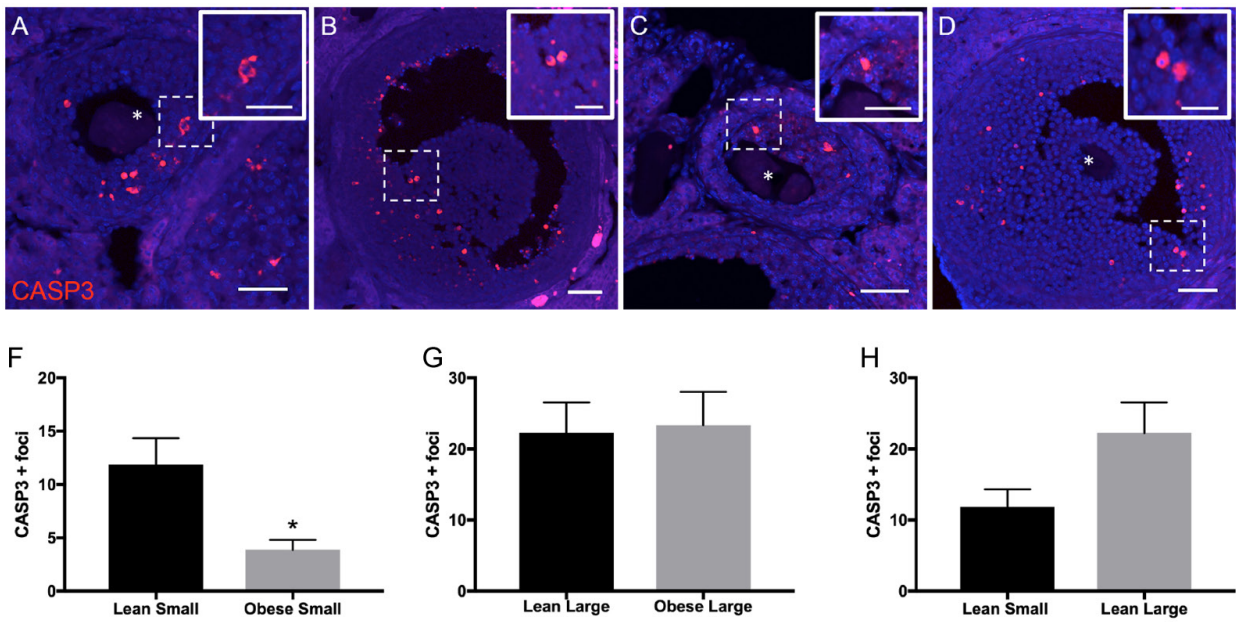

$\mathrm{H}$

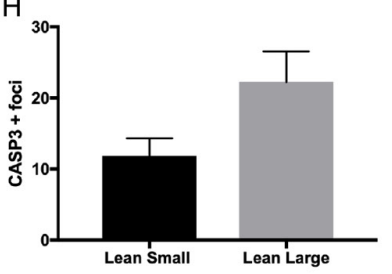

E
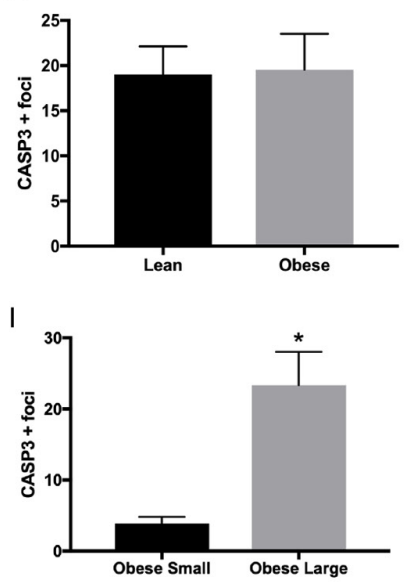

Figure 4 Effect of progressive obesity on cellular apoptosis in the ovary. A primary antibody directed against cleaved CASP3 was used to determine ovarian localization in (A) small follicles of lean mice; (B) large follicles of lean mice; (C) small follicles of obese mice and (D) large follicles of obese mice. Red punctate stain indicates cleaved CASP3 while cellular DNA is stained in blue; scale bar $=50 \mu \mathrm{m}(25 \mu \mathrm{m}$ for insets). Asterisk indicates oocyte. Bar charts present mean number of positive CASP3 foci \pm S.E.M. in (E) all follicles; (F) small follicles; (G) large follicles; (H) lean small/large follicles; (I) obese small/large follicles; $* P<0.05$.

\section{Ovarian BRCA1 levels are not impacted by obesity}

BRCA1 protein abundance was detected in oocytes of all follicle stages, as well as theca cells, stromal cells, and there was some modest staining in the granulosa cells of larger follicles (Fig. 5A, B, C and D). Staining intensity visibly increased in the theca cells as follicle size increased. There was no observable effect of obesity on ovarian BRCA1 protein.

Localization of pBRCA $1^{\operatorname{Ser} 1423}$ in the ovary was observed in the granulosa cells and oocyte nucleus (Fig.

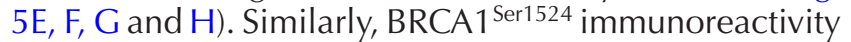
was localized to granulosa cells and the cytoplasm of the oocyte (Fig. 5I, J, K and L). Obesity did not observably alter phosphorylation of pBRCA $1^{\text {Ser1423 }}$ or BRCA $1^{\text {Ser1524. }}$.

\section{Discussion}

The impacts of obesity on health have been well documented, though the percentage of the population, including both adults and children, affected by obesity and obesity-related disorders continues to rise. Reproductive outcomes for obese or overweight women include impaired fertility due to poor oocyte quality (Metwally et al. 2007), disturbances in the menstrual cycle (Mustaqeem et al. 2015), PCOS (Dravecka et al. 2003), and heightened risk of developing ovarian cancer (Olsen et al. 2013). The impacts of obesity may also not be limited to the mother, as offspring exposed to maternal obesity in utero have increased risk for neural tube defects (Huang et al. 2017), glucose intolerance (Hanafi et al. 2016), intrauterine growth restriction (IUGR) (Radulescu et al. 2013), and increased circulating cholesterol and body fat (Desai et al. 2014). Female offspring experiencing the metabolic effects of obesity in utero also exhibit a diminution of the ovarian follicular reserve (Aiken et al. 2016a,b, Clark et al. 2019) and decreases in ovarian vascularity (Chan et al. 2015).

The agouti lethal yellow mouse (KK.Cg-Ay/J) phenotype arises from a mutation in the normal WT non-agouti $(\mathrm{a} / \mathrm{a})$ background that results in ectopic agouti expression (Duhl et al. 1994, Michaud et al. 1994, Klebig et al. 1995). Within the hypothalamus, this increased agouti abundance causes hyperphagia due to melanocyte stimulating hormone receptor inhibition and subsequent dysregulation of alpha-melanocyte-stimulating hormone and cocaine- and amphetamine-regulated transcript ( $\mathrm{Lu}$ et al. 1994). At 6 weeks of age, there is no difference in body weight or circulating insulin level between the lethal yellow agouti mice and their lean counterparts, with an observable increase in both body weight and insulin at 12 weeks of age (Yang et al. 2012). We have demonstrated using this model that hyperphagia-induced obese mice have basal levels of DNA damage in the ovary and a blunted DDR after genotoxicant exposure (Ganesan et al. 2014, 2017, Nteeba et al. 2014a, 2017). Importantly, those observations were made in mice that were 14 weeks of age and older. This study elected to use mice that were younger, 10 weeks of age, in order to avoid the confounding effect of reduced primordial follicle number which we previously noted from 12 weeks of age onwards (Nteeba et al. 2014b) and to facilitate observance of initiating events within the ovary that alter the DDR in the ovary of an obese female.

ATM is first activated by the MRE11, RAD50, and NBS1 (MRN) complex and stabilized at the location of the DNA DSBs by autophosphorylation at serine 1981 (So et al. 2009). Ablation of this autophosphorylation site results in cessation of ATM's ability to phosphorylate any downstream targets (So et al. 2009). Further, mutations 

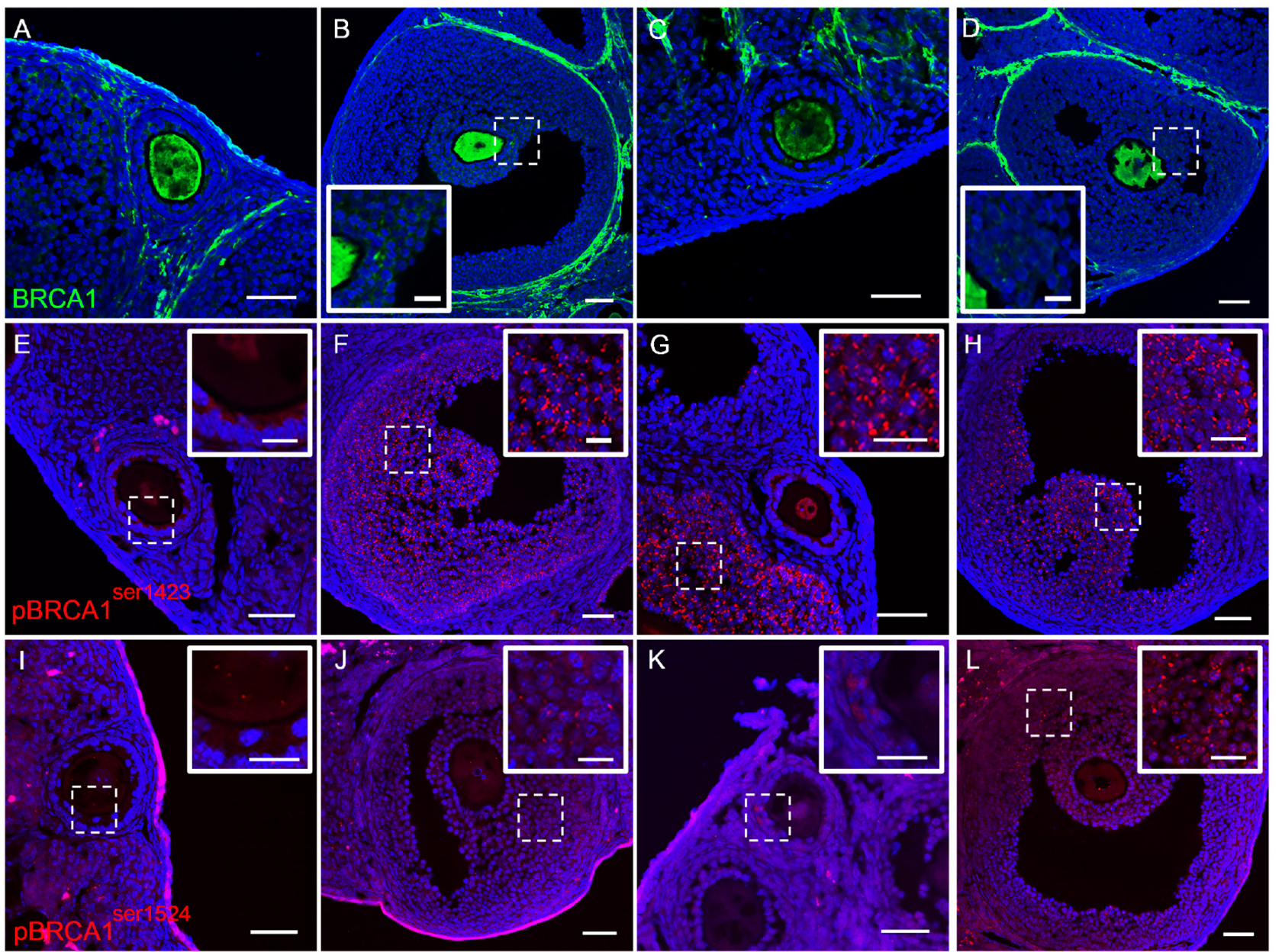

Figure 5 Progressive obesity impacts on BRCA1 DNA repair response. Primary antibodies directed against BRCA1 in (A) small follicles of lean

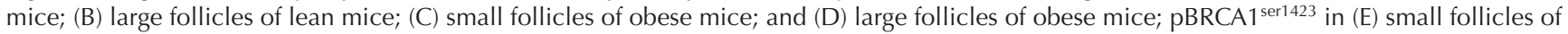
lean mice; (F) large follicles of lean mice; (G) small follicles of obese mice; (H) large follicles of obese mice; pBRCA1 ${ }^{\text {ser1524 }}$; (I) small follicles of lean mice; (J) large follicles of lean mice; (K) small follicles of obese mice; (L) large follicles of obese mice. Green stain indicates BRCA1 and red stain indicates pBRCA $^{\mathrm{ser} 1423}$ or pBRCA ${ }^{\mathrm{ser} 1524}$ while cellular DNA is stained in blue; scale bar $=50 \mu \mathrm{m}(25 \mu \mathrm{m}$ for insets $)$.

in the Atm gene elicit an inadequate response to DNA damage, increasing both radiation sensitivity and cancer predisposition as a result of faulty DNA repair (Boder \& Sedgwick 1958). We discovered more basal ATM in the ovary of an obese female, though no measurable differences in the amount of total phosphorylated ATM $^{\text {Ser1981 }}$ were observed. Despite the lack of an effect on total pATM ${ }^{\text {Ser1981 }}$, pATM ${ }^{\text {Ser1981 }}$ abundance was elevated in smaller compared to larger follicles in the obese mice, suggesting both dysfunction in ATM phosphorylation in a follicle maturation stage dependent manner. This is consistent with our previous findings that ATM acts as a sensor for ovarian DNA damage (Ganesan et al. 2014, 2017, Ganesan \& Keating 2015, 2016), and that there is a disconnect between elevated ATM and the subsequent activation of ATM downstream proteins in the ovary of an obese female (Ganesan et al. 2014, 2017).

The presence of $\gamma \mathrm{H} 2 \mathrm{AX}$ is considered the gold standard for double strand break localization
(Fernandez-Capetillo et al. 2004), and H2AX is activated upon phosphorylation by ATM at the DNA break site (Meier et al. 2007, Savic et al. 2009). In support of our previous findings of increased ATM and $\gamma \mathrm{H} 2 \mathrm{AX}$ in the obese ovary both basally and in response to a genotoxicant exposure (Ganesan et al. 2014, 2017), there was increased abundance of $\gamma \mathrm{H} 2 \mathrm{AX}$ positive foci in the ovaries from the obese mouse in both small and large follicles. Despite a follicular stage dependent pattern of elevated ATM and follicle-stage increased

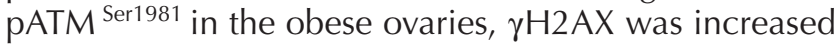
in all stages analyzed due to obesity. This could indicate

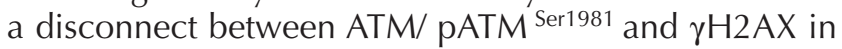
the obese ovary.

A higher BMI contributes to the development of DNA lesions (Wlodarczyk et al. 2018), but the origins of the elevated amounts of DNA DSBs remain to be elucidated. It is presumable that these lesions are occurring due to the increased inflammation and enhanced ROS 
production that are present during obesity (Igosheva et al. 2010, Donmez-Altuntas et al. 2014, Setayesh et al. 2018). Proinflammatory cytokines TNF $\alpha$, interleukin family members, and NF- $\mathrm{\kappa B}$ are implicated in ovarian pathologies such as endometriosis (Carlberg et al. 2000), ovarian hyperstimulation (Ma et al. 2010), and cancer (DiDonato et al. 2012). Increased amounts of DNA damage in the ovary, particularly in the oocyte, may impair oocyte developmental competence and result in aberrant implantation or trophoblast invasion (Robker 2008). Obesity also disrupts ovarian function via the alteration of the estrous cycle in rodents (Nteeba et al. 2014b, Bazzano et al. 2015), and depleting the primordial follicle pool (Nteeba et al. 2014b, Wang et al. 2014) concurrent with the increase of follicle activation and follicular atresia (Nteeba et al. 2014b, Wang et al. 2014, Bazzano et al. 2015, Skaznik-Wikiel et al. 2016). Thus, our findings recapitulate our previous observations (Ganesan et al. 2014, 2017) and support that basal DNA damage is present in the ovary of obese females.

If the DNA damage within a cell cannot be repaired, the cell may be shunted toward apoptosis. Apoptosis is coordinated by the activation of caspases, which then proteolytically process various cellular targets through the amplification of apoptotic signals (Cohen 1997). Caspase 3 (CASP3) is an apoptotic protease involved in ovarian granulosa (Matikainen et al. 2001) and luteal (Carambula et al. 2002) cell death, though is not required for oocyte death (Matikainen et al. 2001). Further, increased granulosa cell apoptosis has been reported with obesity (Walzem \& Chen 2014). We and others have shown a dramatic increase in ovarian CASP3 positive cells after a genotoxicant exposure (Plowchalk \& Mattison 1991, Ganesan \& Keating 2015, Nguyen et al. 2018, Clark \& Keating 2019, Luan et al. 2019). There was no increase in total ovarian CASP3 positive foci due to obesity, however, an interesting shift occurred in that the obese ovary had less CASP3 in small compared to large follicles, compared to the lean ovary in which the pattern was switched. Thus, similar to the observations with ATM $^{\text {Ser1981, there may }}$ be follicle type-specific alterations due to obesity that could alter fertility in females. The accumulation of DNA DSBs in a transcriptionally quiescent cell like the meiotically arrested oocyte can either induce oocyte death or stimulate DNA repair in order to recover oocyte integrity and promote survival (Carroll \& Marangos 2013, Collins \& Jones 2016). It is also possible that basal DNA damage isn't being repaired adequately, and that the damaged follicles are not being shunted toward demise, contributing to poor oocyte quality. This finding is consistent with our findings of reduced CASP3 and cytochrome $\mathrm{C}$ in $\mathrm{Atm}^{+/-}$mice exposed to the genotoxicant phosphoramide mustard in which ATM deficiency resulted in fewer ovarian follicles being depleted by the toxicant exposure (Clark \& Keating 2019), supporting that ATM plays a role in mediating follicular atresia.

Another critical protein required for efficient DNA repair is BRCA1. Phosphorylation of BRCA1 at $\operatorname{Ser}^{1423}$ and $\mathrm{Ser}^{1524}$ is ATM-dependent in the event of DNA damage (Cortez et al. 1999). Women with a mutated allele of the Brca1 gene have increased risk of tumor development, specifically breast and ovarian cancers, as a result of defective DNA repair (Robson et al. 1998). We have previously demonstrated that progressive obesity reduced ovarian BRCA1 protein in mice aged 18 and 24 weeks (Ganesan et al. 2014, 2017). At the earlier stage of obesity examined in this study (10 weeks of age), there were no observable differences in basal BRCA1 abundance or in the amount of phosphorylated $B R C A 1^{\operatorname{Ser} 1423}$ or $B R C A 1^{\text {Ser1524 }}$ relative to lean ovaries. Interestingly, DNA repair gene and protein activity in the ovary decrease with age (Titus et al. 2013, Govindaraj et al. 2015), emphasizing the importance of the DDR in ovarian ageing and fertility. Thus, the obesity-induced decline in BRCA1 that we previously noted may be influenced by either attainment of a certain threshold of obesity or by ovarian age.

\section{Conclusions}

Taken together, this study confirmed that there is elevated basal DNA damage in the ovaries of obese mice. In addition, the data confirms greater ATM protein abundance in large compared to small follicles (both lean and obese) and that there is dysfunction in ATM phosphorylation due to obesity. Further, we also discovered a reduction in CASP3 protein in small follicles in the obese relative to lean females. The model used eliminates the confounding effects of different diets since the obese mice overeat the same diet as the lean mice. We did not note any effect on BRCA1 at this stage of obesity, potentially suggesting that there is either a threshold of obesity that must be attained before reduced BRCA1 is noted, or that ovarian aging coupled with obesity has an additive effect on BRCA1 abundance. While obesity is not a complete barrier to healthy fertility, the evidence that obesity has negative effects on ovarian function and oocyte quality is unequivocal. Estimation of ovarian DNA damage and the resulting alterations in DDR during obesity could potentially aid in diagnosis and prevention of obesityrelated reproductive disorders and consideration of DDR-initiating proteins as markers of ovarian health have merit.

\section{Supplementary materials}

This is linked to the online version of the paper at https://doi. org/10.1530/REP-20-0070. 


\section{Declaration of interest}

The authors declare that there is no conflict of interest that could be perceived as prejudicing the impartiality of the research reported.

\section{Funding}

This work was funded by the Bailey Career Development Award from lowa State University (A F K).

\section{Author contribution statement}

K L C and A F K contributed to experimental conception and design. $K L \mathrm{C}$ and $\mathrm{C} M \mathrm{R}$ performed the experiments and $\mathrm{K} L \mathrm{C}$ analyzed the data. $\mathrm{KL} \mathrm{C}$ wrote the first draft of the paper. All authors reviewed and approved the final manuscript.

\section{References}

Aiken CE, Tarry-Adkins JL \& Ozanne SE 2016a Transgenerational effects of maternal diet on metabolic and reproductive ageing. Mammalian Genome 27 430-439. (https://doi.org/10.1007/s00335-016-9631-1)

Aiken CE, Tarry-Adkins JL, Penfold NC, Dearden L \& Ozanne SE $2016 b$ Decreased ovarian reserve, dysregulation of mitochondrial biogenesis, and increased lipid peroxidation in female mouse offspring exposed to an obesogenic maternal diet. FASEB Journal 30 1548-1556. (https://doi. org/10.1096/fj.15-280800)

Azzara A, Pirillo C, Giovannini C, Federico G \& Scarpato R 2016 Different repair kinetic of DSBs induced by mitomycin $C$ in peripheral lymphocytes of obese and normal weight adolescents. Mutation Research 789 9-14. (https://doi.org/10.1016/j.mrfmmm.2016.05.001)

Bazhan NM, Yakovleva TV, Kazantseva AY \& Makarova EN 2013 Exaggerated anorexigenic response to restraint stress in $\mathrm{A}(\mathrm{y})$ mice is associated with elevated CRFR2 mRNA expression in the hypothalamus. Physiology and Behavior 120 19-25. (https://doi.org/10.1016/j.physbeh.2013.06.023)

Bazzano MV, Torelli C, Pustovrh MC, Paz DA \& Elia EM 2015 Obesity induced by cafeteria diet disrupts fertility in the rat by affecting multiple ovarian targets. Reproductive Biomedicine Online 31 655-667. (https:// doi.org/10.1016/j.rbmo.2015.08.004)

Boder E \& Sedgwick RP 1958 Ataxia-telangiectasia; a familial syndrome of progressive cerebellar ataxia, oculocutaneous telangiectasia and frequent pulmonary infection. Pediatrics 21 526-554.

Brewer CJ \& Balen AH 2010 The adverse effects of obesity on conception and implantation. Reproduction 140 347-364. (https://doi.org/10.1530/ REP-09-0568)

Byers SL, Wiles MV, Dunn SL \& Taft RA 2012 Mouse estrous cycle identification tool and images. PLoS ONE 7 e35538. (https://doi. org/10.1371/journal.pone.0035538)

Carambula SF, Matikainen T, Lynch MP, Flavell RA, Goncalves PB, Tilly JL \& Rueda BR 2002 Caspase-3 is a pivotal mediator of apoptosis during regression of the ovarian corpus luteum. Endocrinology 143 1495-1501. (https://doi.org/10.1210/endo.143.4.8726)

Carlberg M, Nejaty J, Froysa B, Guan Y, Soder O \& Bergqvist A 2000 Elevated expression of tumour necrosis factor alpha in cultured granulosa cells from women with endometriosis. Human Reproduction 15 1250-1255. (https://doi.org/10.1093/humrep/15.6.1250)

Carroll J \& Marangos P 2013 The DNA damage response in mammalian oocytes. Frontiers in Genetics 4 117. (https://doi.org/10.3389/fgene.2013.00117)

Cerda C, Sanchez C, Climent B, Vazquez A, Iradi A, El Amrani F, Bediaga A \& Saez GT 2014 Oxidative stress and DNA damage in obesity-related tumorigenesis. Advances in Experimental Medicine and Biology 824 5-17. (https://doi.org/10.1007/978-3-319-07320-0_2)

Chan KA, Tsoulis MW \& Sloboda DM 2015 Early-life nutritional effects on the female reproductive system. Journal of Endocrinology 224 R45-R62. (https://doi.org/10.1530/JOE-14-0469)
Chu SY, Callaghan WM, Kim SY, Schmid CH, Lau J, England LJ \& Dietz PM 2007 Maternal obesity and risk of gestational diabetes mellitus. Diabetes Care 30 2070-2076. (https://doi.org/10.2337/dc06-2559a)

Clark KL \& Keating AF 2020 Ataxia telangiectasia mutated coordinates the ovarian DNA repair and atresia-initiating response to phosphoramide mustard. Biology of Reproduction 102 248-260. (https://doi.org/10.1093/ biolre/ioz160)

Clark KL, Talton OO, Ganesan S, Schulz LC \& Keating AF 2019 Developmental origins of ovarian disorder: impact of maternal lean gestational diabetes on the offspring ovarian proteome in micedagger. Biology of Reproduction 101 771-781. (https://doi.org/10.1093/biolre/ ioz116)

Cohen GM 1997 Caspases: the executioners of apoptosis. Biochemical Journal 326 1-16. (https://doi.org/10.1042/bj3260001)

Colditz GA, Willett WC, Rotnitzky A \& Manson JE 1995 Weight gain as a risk factor for clinical diabetes mellitus in women. Annals of Internal Medicine 122 481-486. (https://doi.org/10.7326/0003-4819-122-7199504010-00001)

Collins JK \& Jones KT 2016 DNA damage responses in mammalian oocytes. Reproduction 152 R15-R22. (https://doi.org/10.1530/REP-16-0069)

Compston JE 2001 Sex steroids and bone. Physiological Reviews 81 419-447. (https://doi.org/10.1152/physrev.2001.81.1.419)

Cortez D, Wang Y, Qin J \& Elledge SJ 1999 Requirement of ATMdependent phosphorylation of BRCA1 in the DNA damage response to double-strand breaks. Science 286 1162-1166. (https://doi.org/10.1126/ science.286.5442.1162)

Coulam CB, Adamson SC \& Annegers JF 1986 Incidence of premature ovarian failure. Obstetrics and Gynecology 67 604-606. (https://doi. org/10.1097/00006254-198703000-00020)

Cozzo AJ, Fuller AM \& Makowski L 2017 Contribution of adipose tissue to development of cancer. Comprehensive Physiology 8 237-282. (https:// doi.org/10.1002/cphy.c170008)

Desai M, Jellyman JK, Han G, Beall M, Lane RH \& Ross MG 2014 Maternal obesity and high-fat diet program offspring metabolic syndrome. American Journal of Obstetrics and Gynecology 211 237.e1-237.e13. (https://doi.org/10.1016/j.ajog.2014.03.025)

Didonato JA, Mercurio F \& Karin M 2012 NF-kappaB and the link between inflammation and cancer. Immunologic Research 246 379-400. (https:// doi.org/10.1111/j.1600-065X.2012.01099.x)

Donmez-Altuntas H, Sahin F, Bayram F, Bitgen N, Mert M, Guclu K, Hamurcu Z, Aribas S, Gundogan K \& Diri H 2014 Evaluation of chromosomal damage, cytostasis, cytotoxicity, oxidative DNA damage and their association with body-mass index in obese subjects. Mutation Research: Genetic Toxicology and Environmental Mutagenesis 771 30-36. (https://doi.org/10.1016/j.mrgentox.2014.06.006)

Dravecka I, Lazurova I \& Kraus V 2003 Obesity is the major factor determining an insulin sensitivity and androgen production in women with anovulary cycles. Bratislavske Lekarske Listy 104 393-399.

Duhl DM, Stevens ME, Vrieling H, Saxon PJ, Miller MW, Epstein CJ \& Barsh GS 1994 Pleiotropic effects of the mouse lethal yellow (Ay) mutation explained by deletion of a maternally expressed gene and the simultaneous production of agouti fusion RNAs. Development 120 1695-1708.

Falck J, Mailand N, Syljuasen RG, Bartek J \& Lukas J 2001 The ATMChk2-Cdc25A checkpoint pathway guards against radioresistant DNA synthesis. Nature 410 842-847. (https://doi.org/10.1038/35071124)

Fernandez-Capetillo O, Lee A, Nussenzweig M \& Nussenzweig A 2004 H2AX: the histone guardian of the genome. DNA Repair 3 959-967. (https://doi.org/10.1016/j.dnarep.2004.03.024)

Ganesan S \& Keating AF 2015 Phosphoramide mustard exposure induces DNA adduct formation and the DNA damage repair response in rat ovarian granulosa cells. Toxicology and Applied Pharmacology 282 252-258. (https://doi.org/10.1016/j.taap.2014.11.017)

Ganesan S \& Keating AF 2016 The ovarian DNA damage repair response is induced prior to phosphoramide mustard-induced follicle depletion, and ataxia telangiectasia mutated inhibition prevents PM-induced follicle depletion. Toxicology and Applied Pharmacology 292 65-74. (https://doi.org/10.1016/j.taap.2015.12.010)

Ganesan S, Nteeba J \& Keating AF 2014 Enhanced susceptibility of ovaries from obese mice to 7,12-dimethylbenz[a]anthracene-induced DNA damage. Toxicology and Applied Pharmacology 281 203-210. (https:// doi.org/10.1016/j.taap.2014.10.004) 
Ganesan S, Nteeba J \& Keating AF 2015 Impact of obesity on 7,12-dimethylbenz[a]anthracene-induced altered ovarian connexin gap junction proteins in female mice. Toxicology and Applied Pharmacology 282 1-8. (https://doi.org/10.1016/j.taap.2014.10.020)

Ganesan S, Nteeba J, Madden JA \& Keating AF 2017 Obesity alters phosphoramide mustard-induced ovarian DNA repair in mice. Biology of Reproduction 96 491-501. (https://doi.org/10.1095/ biolreprod.116.143800)

Gatei M, Scott SP, Filippovitch I, Soronika N, Lavin MF, Weber B \& Khanna KK 2000 Role for ATM in DNA damage-induced phosphorylation of BRCA1. Cancer Research 60 3299-3304.

Gesink Law DC, Maclehose RF \& Longnecker MP 2007 Obesity and time to pregnancy. Human Reproduction 22 414-420. (https://doi.org/10.1093/ humrep/del400)

Govindaraj V, Keralapura Basavaraju R \& Rao AJ 2015 Changes in the expression of DNA double strand break repair genes in primordial follicles from immature and aged rats. Reproductive Biomedicine Online 30 303-310. (https://doi.org/10.1016/j.rbmo.2014.11.010)

Hales CM, Carroll MD, Fryar CD \& Ogden CL 2017 Prevalence of Obesity Among Adults and Youth: United States, 2015-2016, 288 ed. Hyattsville MD: National Center for Health Statistics.

Hanafi MY, Saleh MM, Saad MI, Abdelkhalek TM \& Kamel MA 2016 Transgenerational effects of obesity and malnourishment on diabetes risk in F2 generation. Molecular and Cellular Biochemistry 412 269-280. (https://doi.org/10.1007/s11010-015-2633-6)

Himbert C, Thompson H \& Ulrich CM 2017 Effects of intentional weight loss on markers of oxidative stress, DNA repair and telomere length - a systematic review. Obesity Facts 10 648-665. (https://doi. org/10.1159/000479972)

Hirshfield AN 1991 Development of follicles in the mammalian ovary. International Review of Cytology 124 43-101. (https://doi.org/10.1016/ s0074-7696(08)61524-7)

Huang HY, Chen HL \& Feng LP 2017 Maternal obesity and the risk of neural tube defects in offspring: a meta-analysis. Obesity Research and Clinical Practice 11 188-197. (https://doi.org/10.1016/j. orcp.2016.04.005)

Igosheva N, Abramov AY, Poston L, Eckert JJ, Fleming TP, Duchen MR \& Mcconnell J 2010 Maternal diet-induced obesity alters mitochondrial activity and redox status in mouse oocytes and zygotes. PLOS ONE 5 e10074. (https://doi.org/10.1371/journal.pone.0010074)

Kang YJ, Wang HW, Cheon SY, Lee HJ, Hwang KM \& Yoon HS 2016 Associations of obesity and dyslipidemia with intake of sodium, fat, and sugar among koreans: a qualitative systematic review. Clinical Nutrition Research 5 290-304. (https://doi.org/10.7762/cnr.2016.5.4.290)

Klebig ML, Wilkinson JE, Geisler JG \& Woychik RP 1995 Ectopic expression of the agouti gene in transgenic mice causes obesity, features of type II diabetes, and yellow fur. PNAS 92 4728-4732. (https://doi.org/10.1073/ pnas.92.11.4728)

Koegler FH, Schaffhauser AO, Mynatt RL, York DA \& Bray GA 1999 Macronutrient diet intake of the lethal yellow agouti (Ay/a) mouse. Physiology and Behavior 67 809-812. (https://doi.org/10.1016/s0031 9384(99)00104-3)

Lavie CJ, Milani RV \& Ventura HO 2009 Obesity and cardiovascular disease: risk factor, paradox, and impact of weight loss. Journal of the American College of Cardiology 53 1925-1932. (https://doi. org/10.1016/j.jacc.2008.12.068)

Liu Q, Turner KM, Alfred Yung WK, Chen K \& Zhang W 2014 Role of AKT signaling in DNA repair and clinical response to cancer therapy. NeuroOncology 16 1313-1323. (https://doi.org/10.1093/neuonc/nou058)

Lu D, Willard D, Patel IR, Kadwell S, Overton L, Kost T, Luther M, Chen W, Woychik RP \& Wilkison WO 1994 Agouti protein is an antagonist of the melanocyte-stimulating-hormone receptor. Nature 371 799-802. (https://doi.org/10.1038/371799a0)

Luan Y, Edmonds ME, Woodruff TK \& Kim SY 2019 Inhibitors of apoptosis protect the ovarian reserve from cyclophosphamide. Journal of Endocrinology 240 243-256. (https://doi.org/10.1530/JOE-18-0370)

Ma CH, Yan LY, Qiao J, Sha W, Li L, Chen Y \& Sun QY 2010 Effects of tumor necrosis factor-alpha on porcine oocyte meiosis progression, spindle organization, and chromosome alignment. Fertility and Sterility 93 920-926. (https://doi.org/10.1016/j.fertnstert.2009.01.131)

Matikainen T, Perez GI, Zheng TS, Kluzak TR, Rueda BR, Flavell RA \& Tilly JL 2001 Caspase-3 gene knockout defines cell lineage specificity for programmed cell death signaling in the ovary. Endocrinology 142 2468-2480. (https://doi.org/10.1210/endo.142.6.8078)

Meier A, Fiegler H, Munoz P, Ellis P, Rigler D, Langford C, Blasco MA, Carter N \& Jackson SP 2007 Spreading of mammalian DNA-damage response factors studied by ChIP-chip at damaged telomeres. EMBO Journal 26 2707-2718. (https://doi.org/10.1038/sj.emboj.7601719)

Metwally M, Cutting R, Tipton A, Skull J, Ledger WL \& Li TC 2007 Effect of increased body mass index on oocyte and embryo quality in IVF patients. Reproductive Biomedicine Online 15 532-538. (https://doi. org/10.1016/s1472-6483(10)60385-9)

Meulmeester E, Pereg Y, Shiloh Y \& Jochemsen AG 2005 ATM-mediated phosphorylations inhibit Mdmx/Mdm2 stabilization by HAUSP in favor of p53 activation. Cell Cycle 4 1166-1170. (https://doi.org/10.4161/ cc.4.9.1981)

Michaud EJ, Bultman SJ, Klebig ML, Van Vugt MJ, Stubbs LJ, Russell LB \& Woychik RP 1994 A molecular model for the genetic and phenotypic characteristics of the mouse lethal yellow (Ay) mutation. PNAS 91 2562-2566. (https://doi.org/10.1073/pnas.91.7.2562)

Mosca L, Manson JE, Sutherland SE, Langer RD, Manolio T \& BarrettConnor E 1997 Cardiovascular disease in women: a statement for healthcare professionals from the American Heart Association. Writing Group. Circulation 96 2468-2482. (https://doi.org/10.1161/01. cir.96.7.2468)

Mustaqeem M, Sadullah S, Waqar W, Farooq MZ, Khan A \& Fraz TR 2015 Obesity with irregular menstrual cycle in young girls. Mymensingh Medical Journal 24 161-167.

Nagle CM, Dixon SC, Jensen A, Kjaer SK, Modugno F, deFazio A, Fereday S, Hung J, Johnatty SE, Australian Ovarian Cancer Study Group et al. 2015 Obesity and survival among women with ovarian cancer: results from the Ovarian Cancer Association Consortium. British Journal of Cancer 113 817-826. (https://doi.org/10.1038/bjc.2015.245)

Nguyen QN, Zerafa N, Liew SH, Morgan FH, Strasser A, Scott CL, Findlay JK, Hickey M \& Hutt KJ 2018 Loss of PUMA protects the ovarian reserve during DNA-damaging chemotherapy and preserves fertility. Cell Death and Disease 9 618. (https://doi.org/10.1038/s41419-0180633-7)

Nteeba J, Ross JW, Perfield JW, 2ND \& Keating AF 2013 High fat diet induced obesity alters ovarian phosphatidylinositol-3 kinase signaling gene expression. Reproductive Toxicology 42 68-77. (https://doi. org/10.1016/j.reprotox.2013.07.026)

Nteeba J, Ganesan S \& Keating AF 2014a Impact of obesity on ovotoxicity induced by 7,12-dimethylbenz[a]anthracene in mice. Biology of Reproduction 90 68. (https://doi.org/10.1095/biolreprod.113.114215)

Nteeba J, Ganesan S \& Keating AF 2014b Progressive obesity alters ovarian folliculogenesis with impacts on pro-inflammatory and steroidogenic signaling in female mice. Biology of Reproduction 91 86. (https://doi. org/10.1095/biolreprod.114.121343)

Nteeba J, Ganesan S, Madden JA, Dickson MJ \& Keating AF 2017 Progressive obesity alters ovarian insulin, phosphatidylinositol-3 kinase, and chemical metabolism signaling pathways and potentiates ovotoxicity induced by phosphoramide mustard in mice. Biology of Reproduction 96 478-490. (https://doi.org/10.1095/biolreprod.116.143818)

Olsen CM, Nagle CM, Whiteman DC, Ness R, Pearce CL, Pike MC, Rossing MA, Terry KL, Wu AH, Australian Cancer Study (Ovarian Cancer) et al. 2013 Obesity and risk of ovarian cancer subtypes: evidence from the Ovarian Cancer Association Consortium. Endocrine-Related Cancer 20 251-262. (https://doi.org/10.1530/ERC-12-0395)

Pasquali R \& Casimirri F 1993 The impact of obesity on hyperandrogenism and polycystic ovary syndrome in premenopausal women. Clinical Endocrinology 39 1-16. (https://doi.org/10.1111/j.1365-2265.1993. tb01744.x)

Plowchalk DR \& Mattison DR 1991 Phosphoramide mustard is responsible for the ovarian toxicity of cyclophosphamide. Toxicology and Applied Pharmacology 107 472-481. (https://doi.org/10.1016/0041008x(91)90310-b)

Radulescu L, Ferechide D \& Popa F 2013 The importance of fetal gender in intrauterine growth restriction. Journal of Medicine and Life 6 38-39.

Robker RL 2008 Evidence that obesity alters the quality of oocytes and embryos. Pathophysiology 15 115-121. (https://doi.org/10.1016/j. pathophys.2008.04.004)

Robson M, Gilewski T, Haas B, Levin D, Borgen P, Rajan P, Hirschaut $Y$, Pressman P, Rosen PP, Lesser ML et al. 1998 BRCA-associated breast 
cancer in young women. Journal of Clinical Oncology 16 1642-1649. (https://doi.org/10.1200/JCO.1998.16.5.1642)

Savic V, Yin B, Maas NL, Bredemeyer AL, Carpenter AC, Helmink BA, Yanglott KS, Sleckman BP \& Bassing CH 2009 Formation of dynamic gamma$\mathrm{H} 2 \mathrm{AX}$ domains along broken DNA strands is distinctly regulated by ATM and MDC1 and dependent upon H2AX densities in chromatin. Molecular Cell 34 298-310. (https://doi.org/10.1016/j.molcel.2009.04.012)

Scheyer O, Rahman A, Hristov H, Berkowitz C, Isaacson RS, Diaz Brinton R \& Mosconi L 2018 Female sex and Alzheimer's risk: the menopause connection. Journal of Prevention of Alzheimer's Disease $\mathbf{5}$ 225-230. (https://doi.org/10.14283/jpad.2018.34)

Schneider CA, Rasband WS \& Eliceiri KW 2012 NIH Image to Image): 25 years of image analysis. Nature Methods 9 671-675. (https://doi. org/10.1038/nmeth.2089)

Setayesh T, Nersesyan A, Misik M, Ferk F, Langie S, Andrade VM, Haslberger A \& Knasmuller S 2018 Impact of obesity and overweight on DNA stability: few facts and many hypotheses. Mutation Research 777 64-91. (https://doi.org/10.1016/j.mrrev.2018.07.001)

Sheffield JS, Butler-Koster EL, Casey BM, Mcintire DD \& Leveno KJ 2002 Maternal diabetes mellitus and infant malformations. Obstetrics and Gynecology 100 925-930. (https://doi.org/10.1016/s00297844(02)02242-1)

Skaznik-Wikiel ME, Swindle DC, Allshouse AA, Polotsky AJ \& McManaman JL 2016 High-fat diet causes subfertility and compromised ovarian function independent of obesity in mice. Biology of Reproduction 94 108. (https://doi.org/10.1095/biolreprod.115.137414)

So S, Davis AJ \& Chen DJ 2009 Autophosphorylation at serine 1981 stabilizes ATM at DNA damage sites. Journal of Cell Biology 187 977-990. (https://doi.org/10.1083/jcb.200906064)

Titus S, Li F, Stobezki R, Akula K, Unsal E, Jeong K, Dickler M, Robson M, Moy F, Goswami S et al. 2013 Impairment of BRCA1-related DNA double-strand break repair leads to ovarian aging in mice and humans. Science Translational Medicine 5 172ra21. (https://doi.org/10.1126/ scitransImed.3004925)
Walzem RL \& Chen SE 2014 Obesity-induced dysfunctions in female reproduction: lessons from birds and mammals. Advances in Nutrition 5 199-206. (https://doi.org/10.3945/an.113.004747)

Wang N, Luo LL, Xu JJ, Xu MY, Zhang XM, Zhou XL, Liu WJ \& Fu YC 2014 Obesity accelerates ovarian follicle development and follicle loss in rats. Metabolism: Clinical and Experimental 63 94-103. (https://doi. org/10.1016/j.metabol.2013.09.001)

Wlodarczyk M, Jablonowska-Lietz B, Olejarz W \& Nowicka G 2018 Anthropometric and dietary factors as predictors of DNA damage in obese women. Nutrients 10 578. (https://doi.org/10.3390/nu10050578)

Xu H, Barnes GT, Yang Q, Tan G, Yang D, Chou CJ, Sole J, Nichols A, Ross JS, Tartaglia LA et al. 2003 Chronic inflammation in fat plays a crucial role in the development of obesity-related insulin resistance. Journal of Clinical Investigation 112 1821-1830. (https://doi.org/10.1172/ JCI19451)

Yang Z, Norwood KA, Smith JE, Kerl JG \& Wood JR 2012 Genes involved in the immediate early response and epithelial-mesenchymal transition are regulated by adipocytokines in the female reproductive tract. Molecular Reproduction and Development 79 128-137. (https://doi.org/10.1002/ mrd.22006)

Zaki M, Basha W, El-Bassyouni HT, El-Toukhy S \& Hussein T 2018 Evaluation of DNA damage profile in obese women and its association to risk of metabolic syndrome, polycystic ovary syndrome and recurrent preeclampsia. Genes and Diseases 5 367-373. (https://doi.org/10.1016/j. gendis.2018.03.001)

Received 5 February 2020

First decision 9 March 2020

Revised manuscript received 16 August 2020

Accepted 20 August 2020 